\title{
The Academic Profession in China in the Context of Social Transition: An Institutional Perspective
}

\author{
FENGQIAOYAN \\ Institute of Economics of Education/Graduate School of Education, Peking \\ University, China. E-mail: fengqiaoyan@yahoo.com; fqyan@gse.pku.edu.cn
}

The study deals with the academic profession in China. Its characteristics and relationship with changing social institutions are explored by a historical approach and from an institutional perspective, which includes two elements of government and organization. The major findings of this study are summarized below. First, in accordance with China's legal framework, public and private higher education institutions are categorized as different legal entities, a difference that leads to favourable conditions for the academic profession in the public sector and to less favourable conditions in the private sector, and which also obstructs personnel flow and competition between the two sectors. Second, the personnel system has changed significantly since 1978, when it was reformed and the policies became more open. This change is largely led by the central government. As regards faculty hiring and promotion, qualification and performance are emphasized over seniority. As regards remuneration and benefits, the egalitarian approach has gradually been replaced by income gains based on performance. Finally, evidence shows that China's higher education institutions has evolved from so-called danwei governed under a planned system to organizations ruled by the market system, which has caused the academic profession to evolve from a danwei profession into a more organizational one.

\section{Introduction}

The characteristics of the academic profession ${ }^{1}$ are shaped by its social contexts. Economic, political and social factors exert influence on the academic profession 


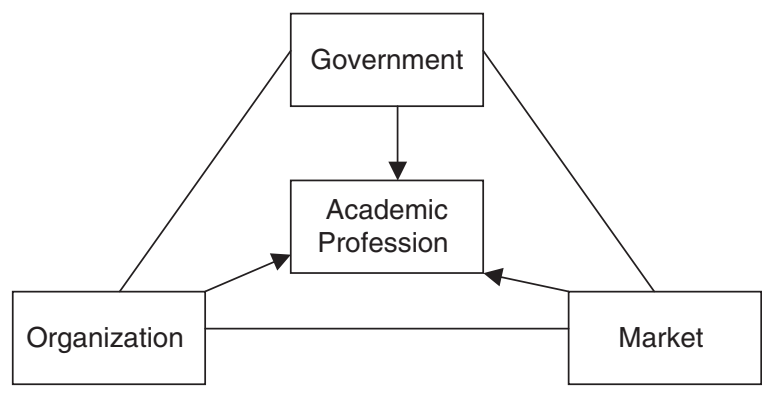

Figure 1. Three institutional elements and the academic profession.

through such institutions as government, market and organizations. Figure 1 illustrates the relations between institutional entities and the academic profession as a general analytical framework. This paper is an attempt to elaborate the social and historical characteristics of the academic profession in China.

Sociological studies on a specific profession devote much attention to its relations with political and economic backgrounds, a context that nevertheless has not always been reflected in studies on the academic profession, as they often emphasize activities at the individual level while largely disregarding how the academic profession is embedded in society as a whole. ${ }^{2}$ The individual approach is effective for closed and static systems, but fails when dealing with open and ever-changing systems. After China adopted reform measures and policy became more open in 1978, drastic changes have taken place. Therefore, it is appropriate to analyze the academic profession in China from an institutional perspective.

The new institutional theory that emerged in the 1970s has been applied to educational studies. It attempts to examine how an institutional environment influences organizational structure and activities. ${ }^{3}$ The theory is often combined with a historical approach. In educational studies, the theoretic framework mostly focuses on the deep structure of schools, as well as on the connection between schools and their embedment in the social system. ${ }^{4}$ There are but a few studies that deal with the academic profession from an institutional perspective. This paper attempts to analyze how governmental policies and organizational arrangements influence the academic profession.

In the past 30 years, fundamental changes have taken place in Chinese society. The changes are related to the transition from a planned economic system to a market-oriented one. The economic transition brought about rapid economic growth. China's GDP grew from RMB 364.5 billion in 1978 to RMB 24 trillion in 2007 at an average annual growth rate of around 10\%: its economic size rose from the tenth to fourth in the world, and China now accounts for $6 \%$ of the world's total economy compared with $1.8 \%$ in $1978 .^{5}$ Changes not only took place in the economic domain, but also in higher education. Enrolments numbers 
Table 1. Academic staff in Chinese public and private universities (2007)

\begin{tabular}{llll}
\hline \hline & & Public university & Private university \\
\hline \multirow{2}{*}{ Organization } & Legal entity & Public unit & Private non-business \\
& Number of universities & 1613 & $295^{*}$ \\
Academic staff & Legal entity & Public unit & Employment-based \\
& & staffing & staffing \\
& Number of faculty & 989,140 & 179,160 \\
\hline \hline
\end{tabular}

Source of data: Yearbook of China Education 2007, People's Education Press.

*Apart from 295 private colleges that are allowed to issue bachelor and associate degrees, there are 318 private independent colleges issuing bachelor degrees and 906 education institutions providing services of self-taught exams. The latter two types are not included in the table.

have increased rapidly and reached a threshold of massification in $2002 .{ }^{6}$ That year, 23 million students were enrolled in higher education; the gross enrolment rate reached $23 \%$ in $2007 .^{7}$ According to statistics, about 80 million students are receiving post-secondary education around the world in $2000 .{ }^{8,9}$ According to recent data from the UNESCO World Conference on Higher Education, total enrolment at tertiary level is 144 million in the world in 2006. It is estimated roughly that China represents one fifth of post-secondary enrolment in the world. Accordingly, the 1 million academic staff in China (see Table 1) also roughly account for one quarter of the global total number of 3.5 million academics. ${ }^{9}$

Social transition exerts an influence on the academic profession through such institutions as government, organization and market. Before the reform, Chinese universities were tightly controlled by the government and the scope of their activities was highly determined by the government. Due to the same constraints, university faculty was also confined to their campus space - no reasonable crossuniversity exchanges existed. ${ }^{10}$ Some scholars labelled the Chinese work unit in general and that of universities in particular as danwei and their members danwei man, which stands in sharp contrast to the organizational man in western organizations. ${ }^{11}$

During the reform of the Chinese higher education system, one of the guiding principles has always been to modify the relationship between universities and the government and to reduce universities' dependence on the government. As a result, Chinese universities are gradually shifting from closed and dependent danwei in the Chinese sense to open and independent organization in the western sense. By the same token, academic staff are also gradually shifting from danwei men whose activities are constrained to the danwei to organizational men whose activities go beyond the limits of the campus. 


\section{The legal framework, the administrative system and the academic profession}

The influence of state laws and the political system should not be neglected when studying the academic profession. ${ }^{12}$ In most European countries, academic staff have the status of civil servants. In the UK and the US, academics have a professional status independent from the government. ${ }^{3}$ To find out how Chinese law defines university faculty, it is necessary to elaborate on how Chinese universities are defined by law. According to the General Principles of the Civil Law of the PRC, which was promulgated in 1986 and has been effective to date, Chinese institutions can be classified into four types, namely enterprises (qiye), state organs (zhengfu jiguan), public units (shiye danwei) and civil units (shetuan). Enterprises, government organs and civil units are comparable to for-profit organizations, public organizations and not-for-profit organizations in western countries respectively, whereas public units are unique to China. ${ }^{13}$ Based on the legal specification, Chinese universities can be divided into public and private ones. Public universities fall into the public unit category while private ones are regarded as civil units, which are labelled specifically as private non-business entities (minban fei qiye).

Depending on the legal status of their institutions, faculty are treated differently. At public universities, staff belong to the public unit staffing system and are paid by central or provincial governmental budget. Their basic salary and welfare (including medical care, housing, pension and unemployment insurances, etc) are favourably secured. In comparison, faculty in the private sector are employees of a particular university, and their remuneration comes solely from the university without any public subsidy. Moreover, welfare provisions are less favourably secured. Consequently, we observed less apparent variation in the public sector and more apparent variation in the private sector as regards remuneration and benefits. The differences in remuneration and job security lead to the fact that job opportunities at public universities are more attractive for talented academics than positions in private institutions. Owing to the different staffing systems, there is little movement of faculty between the two types of universities. Table 1 shows the arrangement for both institutions and faculty. Calculations indicate that public universities account for $84.54 \%$ of the total number and their faculty for $84.66 \%$, whereas private institutions account for $15.46 \%$ and their faculty for $15.34 \%$.

While it is obvious that differences exist between public universities and private universities and among their respective faculties, there is no denying that differences also exist between universities of the same type as well as their staff. In the public sector, there are two types of universities: universities attached to central ministries including the Ministry of Education and universities attached 
Table 2. Comparison of academic staff in different public universities (2007)

\begin{tabular}{llll}
\hline & & Central & Local \\
\hline Organization & Funding source & Central budget & Local budget \\
& Number of universities & $111^{*}$ & 1502 \\
Academic staff & Remuneration & Decent & Poor \\
& Number of faculty & 162,423 & 826,717 \\
\hline
\end{tabular}

Source of data: Yearbook of China Education 2007, People's Education Press. *Out of the 111 universities attached to central ministries, 73 are under direct administration of the Ministry of Education, while the other 38 are under administrative supervision of other central ministries.

to local governments. The former, which are funded by the central budget, can boast of abundant educational resources and higher quality while the latter, funded by local governments, provide fewer educational resources and lower quality. ${ }^{14}$ In general, faculty in the former enjoy higher income than those in the latter. The relation between administration and universities is illustrated in Table 2 .

In addition to the institutional and administrative factors listed in Table 1 and Table 2, the specific research domain in which universities and staff are active also plays a role. This paper cannot discuss all of these factors in detail. But the point is that organization and environment needs to be taken into account to understand better the academic profession.

\section{Evolution of the personnel system and the academic profession}

China's private university system was established in addition to the existing public system in the 1980s. The higher education system reform mainly implicated the public university system. The following section will briefly discuss the situation of private university faculty and then focus on the situation at public universities.

Private universities enjoy a fundamental freedom as they have never been part of the public ownership system, although they sometimes used to engage teachers from the public system on a part-time basis because it was very hard for them to find full-time teachers. ${ }^{15}$ Remuneration structures differ across private universities: some universities for instance adopted 'basic salary+performancebased payment', whereas others use a remuneration system based on the number of hours taught, a mode mainly used for part-timers. ${ }^{16}$

In the following, the academic profession in the public sector is discussed. The academic profession at Chinese universities has experienced ups and downs since the late 1970s. First, after the Cultural Revolution in the late 1970s, new policies 
were adopted concerning intellectuals including university faculty, and their political status was determined as being part of the ruling class. Second, in line with the implementation of the reform measures, the academic community began to have more opportunities for international exchange. Statistics show that $78 \%$ of university presidents attached to the Ministry of Education and $62 \%$ of doctorate supervisors either studied or carried out research overseas. ${ }^{17}$ Simultaneously, the negative impact of a brain drain could be observed. Third, at a certain time there was a significant outflow of faculty to the business sector due to the salary gap. Fourth, from the late 1990s onwards, the academic profession has become attractive as faculty working conditions have been improving and their income has been raised. These changes can be attributed to the national strategy of 'rejuvenating the country through science and education' in general and the 211 and 985 Programmes in particular. ${ }^{18}$ Two cases can illustrate these favourable changes. The first is that the per capita income of faculty at one provincial university was increased from RMB 977 in 1982 to RMB 5879 in 1996, meaning that salaries were quintupled in 14 years. ${ }^{19}$ The other case is that the per capita income at one national university grew from RMB 22,612 in 2000 to RMB 75,738 in 2008, meaning that salaries were more than doubled in 5 years. ${ }^{20}$ In 2005 , the State Taxation Administration listed university faculty as a high-income group.

In the evolution of the academic profession, government policy plays an important role because public universities are considered as public units. Personnel policy in universities includes manpower recruitment and income distribution. Reforms of faculty management relative to manpower recruitment allows universities certain freedom to manage their own faculties. The government provides a certain budget for personnel, but universities can decide how to use it. In the past, teachers may be qualified for an academic rank and be entitled to remunerated accordingly, but whether they can be hired or promoted depends on whether there is a vacant post, which is fixed by government. In the current system, universities can determine positions and remuneration independently. Furthermore, they now determine hiring and promotion based on the needs and the applicants' qualifications. One practice found in some universities is to integrate appraisal with hiring/promotion (pingpin jiehe), as opposed to automatic promotion after a given period of service (pingpin fenkai). For example, Sun Yat-sen University issued Measures for Faculty Staffing Check, Post Setup and the Hiring Process, establishing a post-specific hiring mechanism that abolished the faculty title granting system. ${ }^{21}$

Income distribution is the other important part of personnel policy. Soon, before the reform measures, universities followed a unified sequential salary mechanism. In the past 30 years, the reforms of the salary system have focused on decentralizing decision-making and abolishing egalitarianism. As a result, people are paid more for doing more work because income has been linked to individual performance. ${ }^{22}$ Some of the reform policies are discussed below. 
The Ministry of Education, the State Administration of Labour and the Ministry of Finance made a joint announcement in 1980 and allowed universities to gradually establish a bonus scheme. Some universities attached to the Ministry of Education launched an excess remuneration programme on a piloting basis in 1981, which marks the first time that China added new staff expenses in addition to basic salary, abolishing the past practice of everybody getting an equal share regardless of their performance.

After the Chinese government implemented the third salary system reform in 1985, public units (including higher education institutions) started to follow a structured salary system based on specific posts. Structured salary included four parts: basic salary, post-related salary, salary-based on length of service, and bonuses. Bonuses were linked to individual performance, and its share in the total income was expanded.

After the Chinese government implemented the fourth salary system reform in 1993, salary in public units included post-related salary and allowance. Higher education institutions started to follow a hierarchical salary system based on certificated specialty where faculty income included four parts: basic salary, allowance, welfare and other income.

After identifying a strategy of building world-class universities in 1998, the Chinese government expanded financial support for several universities. In the three years' execution period of the first phase of the 985 Programme, Peking University and Tsinghua University received RMB 1.8 billion respectively besides their regular budget allocation. Part of the RMB 1.8 billion was used for post allowance to increase faculty remuneration. The two universities' practice was adopted by others very soon and post allowance became an important part of faculty income nationwide. In order to better utilize this type of support, the Ministry of Education released Advices on Deepening Income Distribution System Reform in Higher Education Institutions, which required universities to link income directly with post responsibility, performance and contribution. Universities were allowed to determine allowance measures and criteria fitting each university's specific context.

In 2000, the Central Committee Organization Department, the Ministry of Personnel and the Ministry of Education jointly announced Guidelines on Deepening Personnel System Reform in Higher Education Institutions, which identified the objectives of the reform, i.e. to gradually establish a new system that would allow universities freedom in personnel recruitment as well as personnel freedom in choosing jobs, and that would ensure government supervision. The Guidelines also called for the gradual establishment of a budget allocation mechanism based on post salary: remuneration should be based on actual performance, and better performance deserves higher remuneration. As a result, an incentive mechanism stressing high-calibre human resource and key posts was put in place. 
In 2007, the Ministry of Personnel and the Ministry of Education announced Guidelines on the Management of Post Setup in Higher Education Institutions, on the basis of which pilot programmes were set up in a number of universities. A post-specific performance-based salary system was put into place with a new round of salary system reforms in the public units. Faculty income included four parts: post salary, rating-based salary, performance-based salary and allowance. Post salary ensures a minimum income; rating-based salary depends on the length of service; performance-based salary indicates individual contribution; and allowance comes from universities.

In summary, the reform of the faculty income system in Chinese universities has been driven by government policy and has featured a shift from title-based fixed salary to title-based fixed salary plus performance-based salary.

\section{Evolution of university organization and the academic profession}

Remarkable changes have taken place in the way Chinese universities are organized. The changes include a shift from centralization to decentralization, diversification of funding sources, the establishment of an increasingly efficient educational system and a devolution of authority in human resources from government to universities. In the following, these changes are discussed in more detail.

\section{Decentralization of the higher education administration}

China's higher education administration moved back and forth between centralized and decentralized systems. As stipulated in Decision on Reform of the Education System in 1985, a three-layered system was established that included central, provincial and municipal governments. The Outline for Educational Development and Reform in China, which was promulgated in 1993, further demanded that higher education needed to arrive at a new pattern in which colleges are managed at two levels, including central and provincial governments. However, a reform of the higher education administration was not really implemented until late 1990s, when some universities attached to central ministries were transferred to local governments, an event concurrent with a major governmental reform to ensure simple and efficient governments. In all, there were 1080 higher education institutions in China in 1994, among which 367 were under the administration of central ministries and 713 under the administration of local governments. ${ }^{17}$ In 2007 , out of the total 1613 public higher education institutions, 111 institutions were under the administration of central ministries, which accounted for $6.88 \%$; the remaining 1502 local governments accounted for 93.12\% (see Table 2). When comparing the data from 1994 and 2007, we find that there is an obvious tendency towards decentralization. 
Since 1999, China has expanded its higher education enrolment to realize the objective of massification. Central and local universities have played different roles in the massification process. Empirical analyses show that central institutions accommodate a bigger share of postgraduates and have more per capita educational resources, which leads to elite education; on the contrary, local institutions accommodate a bigger share of undergraduates and vocational students and are major contributors to massification. Furthermore, local institutions have less per capita education resources, which accounts for non-elite education.

In the decentralization of the higher education administration, more faculty members work at local institutions, their major function being teaching instead of research. Table 2 shows that faculty in central institutions account for $16.40 \%$, while those in local institutions for $83.60 \%$.

\section{Diversification of funding sources}

From the 1990s onwards, Chinese universities have had to explore diversified funding channels due to insufficient public budget. These channels include university-run businesses, training courses for enterprises, subject studies and research, consulting and donations. ${ }^{17}$

Table 3 shows the composition of funding for China's higher education institutions in 1996, 2000 and 2005. Statistics reveal a remarkable change: the proportion of government budget fell from $80.34 \%$ in 1996 to $42.77 \%$ in 2005 while the proportion of tuition and fees went up from $13.66 \%$ in 1996 to $31.06 \%$ in 2005 .

In general, central institutions have more budget than local ones for at least three reasons. First, the per capita fiscal allocation at central level is higher than at the local level due to the better fiscal condition; secondly, there are several dedicated projects supported by central budget, the funding of which usually goes to central institutions; thirdly, central institutions receive more research funding due to their mission and stronger capacity. There is less discrepancy among central institutions, but more among local institutions due to local economic and fiscal imbalance. ${ }^{23}$

Schools and departments within universities can get research funding and generate resources by training programmes, in addition to the regular appropriation from universities. Empirical analyses show that funding in different disciplines within one university varies remarkably. Research funding and the number of excellent faculty are positive in science and engineering department/schools; student size is an important factor of funding in liberal and social science departments/ schools; funding is also related to how market-oriented is a department/school. ${ }^{24}$

Market factors have adjusted the distribution of academic professions in different disciplines. Table 4 shows the number of faculty specialized in different disciplines and their proportions. In the past 20 years, significant changes have occurred in two disciplines. The proportion of faculty in economics went up from 
Table 3. Composition of funding for China's higher education institutions in 1996, 2000 and 2005

\begin{tabular}{|c|c|c|c|c|c|c|c|}
\hline \multirow[b]{2}{*}{ Year } & \multirow[b]{2}{*}{ Aggregate } & \multicolumn{2}{|c|}{ Government } & \multirow[b]{2}{*}{ Civil contribution } & \multirow[b]{2}{*}{ Social donation } & \multicolumn{2}{|c|}{ (RMB million, \%) } \\
\hline & & & Budget & & & Tuition and fees & Others \\
\hline 1996 & $\begin{array}{r}32,679.29 \\
(100.00)\end{array}$ & $\begin{array}{r}26,255.24 \\
(80.34)\end{array}$ & $\begin{array}{r}22,997.18 \\
\quad(70.37)\end{array}$ & $\begin{array}{l}56.67 \\
(0.17)\end{array}$ & $\begin{array}{r}369.61 \\
(1.13)\end{array}$ & $\begin{array}{r}4,462.37 \\
(13.66)\end{array}$ & $\begin{array}{r}1,535.39 \\
(4.70)\end{array}$ \\
\hline 2000 & $\begin{array}{r}91,335.04 \\
(100.00)\end{array}$ & $\begin{array}{r}53,118.54 \\
(58.16)\end{array}$ & $\begin{array}{r}50,441.73 \\
(55.23)\end{array}$ & $\begin{array}{r}659.41 \\
(0.72)\end{array}$ & $\begin{array}{r}1,518.28 \\
(1.66)\end{array}$ & $\begin{array}{r}19,261.09 \\
(21.09)\end{array}$ & $\begin{array}{r}16,777.72 \\
(18.37)\end{array}$ \\
\hline 2005 & $\begin{array}{c}255,023.708 \\
(100.00)\end{array}$ & $\begin{array}{c}109,083.684 \\
(42.77)\end{array}$ & $\begin{array}{r}104,637.34 \\
(41.03)\end{array}$ & $\begin{array}{r}18,013.154 \\
(7.06)\end{array}$ & $\begin{array}{r}2,107.963 \\
(0.83)\end{array}$ & $\begin{array}{c}79,192.49 .3 \\
(31.06)\end{array}$ & $\begin{array}{r}46,626.411 \\
(18.28)\end{array}$ \\
\hline
\end{tabular}

Source of data: State Statistics Bureau website: http://www.stats.gov.cn/tjsj/ndsj, March 8, 2009.

Parenthetical figures refer to the proportion of the item in aggregate. 
Table 4. Faculty number in different disciplines and their proportion 1980-2007

\begin{tabular}{lllllllllll}
\hline \hline Year & Aggregate & Liberal Arts & Economics & Law & Education & Science & Engineering & Agronomy & Medical science & Others \\
\hline 1980 & 246862 & 56510 & 4280 & 802 & 12517 & 58985 & 70028 & 14655 & 24473 & 4612 \\
& $(100.00)$ & $(22.89)$ & $(1.74)$ & $(0.33)$ & $(5.07)$ & $(23.89)$ & $(28.37)$ & $(5.93)$ & $(9.91)$ & $(1.87)$ \\
1983 & 302919 & 72881 & 8084 & 2213 & 17191 & 72535 & 85070 & 17110 & 27835 & 0 \\
& $(100.00)$ & $(24.06)$ & $(2.67)$ & $(0.73)$ & $(5.68)$ & $(23.95)$ & $(28.08)$ & $(5.65)$ & $(9.18)$ & $(0)$ \\
1990 & 394567 & 100625 & 19226 & 5851 & 32299 & 81943 & 108493 & 18064 & 34066 & 0 \\
& $(100.00)$ & $(24.50)$ & $(4.87)$ & $(1.48)$ & $(8.19)$ & $(20.25)$ & $(27.50)$ & $(4.58)$ & $(8.63)$ & $(0)$ \\
1995 & 400742 & 85527 & 28489 & 9058 & 29139 & 79564 & 114969 & 16254 & 37742 & 0 \\
& $(100.00)$ & $(21.34)$ & $(7.11)$ & $(2.26)$ & $(7.27)$ & $(19.85)$ & $(28.69)$ & $(4.06)$ & $(9.42)$ & $(0)$ \\
2000 & 462772 & 108065 & 37772 & 14097 & 44416 & 78904 & 127758 & 15494 & 36266 & 0 \\
& $(100.00)$ & $(23.35)$ & $(8.16)$ & $(3.05)$ & $(9.60)$ & $(17.05)$ & $(27.60)$ & $(3.35)$ & $(7.84)$ & $(0)$ \\
2003 & 834342 & 216816 & 96187 & 34644 & 74222 & 113307 & 222009 & 22253 & 54904 & $(2.67)$ \\
& $(100.00)$ & $(25.98)$ & $(11.53)$ & $(4.15)$ & $(8.90)$ & $(13.58)$ & $(26.61)$ & $(2.67)$ & $(6.58)$ & $(0)$ \\
2007 & 1168300 & 298506 & 149337 & 51518 & 97511 & 141527 & 318014 & 30966 & 80921 \\
& $(100.00)$ & $(25.55)$ & $(12.78)$ & $(4.41)$ & $(8.35)$ & $(12.11)$ & $(27.22)$ & $(2.66)$ & $(6.92)$ & $(0)$ \\
\hline \hline
\end{tabular}

Notes:

1980 and 1983 data are from Achievement of Education in China Statistics 1949-1983, People's Education Press, which made the following classifications of source data: forestry was included in agronomy; arts in liberal arts; physical education in education; finance and economics in economics; politics and law in law.

1990 data are from Yearbook of China Education 1990, People's Education Press, which made the following classifications of source data: forestry was included in agronomy; arts in liberal arts; physical education in education; finance and economics in economics; politics and law in law. 1995 and 2000 data are from State Statistics Bureau website, accessed 8 March 2009, which made the following classifications of source data: philosophy, literature and history were combined under the heading of liberal arts.

2003 and 2007 data are from Yearbook of China Education 2003 and Yearbook of China Education 2007, People's Education Press, which made the following classifications: philosophy, literature and history were combined under the heading of liberal arts; management was included in economics. Parenthetical figures refer to the proportion of the item in aggregate. 
$1.74 \%$ in 1980 to $12.78 \%$ in 2007 , whereas the proportion of faculty in sciences and engineering declined from $23.89 \%$ in 1980 to $12.11 \%$ in 2007 . This is partially indicative of how universities have adjusted themselves to market demands.

From the above analyses we can conclude that market force has permeated higher education institutions and the academic profession. It has had much impact on the academic profession in terms of the distribution of academic staff across disciplines, funding discrepancy across institutions and disciplines, activities orientation, etc.

\section{Rising efficiency of education}

The student/faculty ratio is an important indicator to measure the efficiency of academic work. Enrolment in China's higher education institutions was suspended between 1966 and 1976, the period of the Cultural Revolution. Nationwide college entrance examination was resumed in 1977. In the following years, enrolment was modest while the number of academic staff was relatively large. Later on, enrolment expanded continuously and ever more drastically since 1999, which has led to a drastic change in the student/faculty ratio. Table 5 shows that the enrolment to faculty ratio in 1980 was only 4.6, but grew to 17.28 in 2007 .

The increase of the student/faculty ratio also indicates that academics have to take care of bigger classes and more students. Moreover, the student population has undergone severe changes because of the higher enrolment levels. Students have become more diverse than before in terms of academic achievement, interest, economic backgrounds, etc. Academic staff are challenged by new cohorts and also by teaching task.

\section{Greater independence in decision making}

For higher education in China after 1985, reform and development have been the major themes. Delegating authority and allowing greater independence in decision making among higher education institutions have been important parts of all higher education reforms.

The government has allowed public universities greater independence in decision making, including the management of faculty, which can be illustrated by the following examples:

(1) Regarding faculty recruitment, universities are allowed to decide independently on the criteria, the required number of staff, the hiring procedures and the candidates as long as the candidates meet the minimum qualifications specified in the Teachers' Law. ${ }^{25}$ Nowadays, more and more universities are starting to see the negative impact brought about by academic inbreeding, and as a result some universities no longer retain their own graduates as faculty. Within 
Table 5. Size of enrolment and faculty 1980-2007

\begin{tabular}{llllll}
\hline \hline Year & $\begin{array}{c}\text { Number of } \\
\text { institutions }\end{array}$ & $\begin{array}{c}\text { Number of associate } \\
\text { and bachelor's } \\
\text { candidates million }\end{array}$ & $\begin{array}{l}\text { Enrolment/ } \\
\text { institutions }\end{array}$ & $\begin{array}{l}\text { Faculty } \\
\text { million }\end{array}$ & $\begin{array}{c}\text { Student/ } \\
\text { faculty } \\
\text { ratio } \Delta\end{array}$ \\
\hline 1980 & $675^{* * *}$ & $1.143712^{* * *}$ & 1694 & $0.246862^{* * *}$ & $4.6^{* *}$ \\
1985 & $1016^{* * *}$ & $1.703115^{* * *}$ & 1676 & $0.344262^{* * *}$ & $5.0^{* *}$ \\
1990 & $1075^{*}$ & 2.0627 & 1919 & $0.3946^{*}$ & $5.23 /$ \\
1995 & 1054 & 2.9064 & 2757 & 0.4007 & 8.90 \\
2000 & 1041 & 5.5609 & 5289 & 0.4628 & 16.3 \\
2005 & 1792 & 15.6178 & 7666 & 0.9658 & 16.85 \\
2006 & 1867 & 17.3884 & 8148 & 1.076 & 17.93 \\
2007 & 1908 & 18.8490 & 9878 & 1.1683 & 17.28 \\
\hline \hline
\end{tabular}

Source of data: Data come from four sources. Unidentified data come from Statistical Bulletin of Education Development in China 1990-2007, http://www.edu.cn/ HomePage/Zhong_guo_jiao_yu/jiao_yu_zi_xun/shu_zi/jiao_yu_fa_zhan/index.shtml, accessed 8 March 2009. Data identified as * come from Yearbook of China Education 1990, People's Education Press. Data identified as ** come from State Statistics Bureau website: http://www.stats.gov.cn/tjsj/ndsj, March $8^{\text {th }}, 2009$. Data identified as *** come from Achievement of Education in China Statistics 1980-1985, People's Education Press.

Note: $\Delta$ refers to the full-time equivalent (FTE) student/faculty ratio;/indicates that for 1990, the 1991 figure is used, as the figure for 1990 is missing.

the public unit staffing system, some universities have started a practice of using HR agencies, meaning that newly hired staff are registered with an external special organization instead of being registered at the universities at which they teach. The new practice aims at reducing mutual dependence between universities and faculty, indicating that universities are taking over fewer responsibilities from faculty.

(2) New policies for hiring and discharging staff are being adopted. More universities are now able to decide independently on promotions of all ranks of faculty. Eligible universities are even allowed to grant titles such as chair professor. Peking University went through an HR system reform in 2003, putting into place mechanisms such as tenure and up-or-out.

(3) Besides the government budget, faculty income includes funds generated by the university as well as additional funding for the social service that individual staff perform. There exists a variety of income items for faculty, including post subsidies from special government-funded projects such as 985 and 211 programmes, research projects, university-run businesses, performance-based 
Table 6. Income structure of academic staff in a university in 2000 and 2008

\begin{tabular}{lcc}
\hline \hline & \multicolumn{3}{c}{ RMB million, \% } \\
\hline Income source & 2000 & 2008 \\
Government & 65.32 & 177.43 \\
& $(32.60)$ & $(21.25)$ \\
University & 135.07 & 657.58 \\
& $(67.40)$ & $(78.75)$ \\
Aggregate & 200.39 & 835.01 \\
& $(100)$ & $(100)$ \\
\hline \hline
\end{tabular}

Source of data: Financial department of the university.

Parenthetical figures refer to the proportion of the item in aggregate.

payment and bonuses. Table 6 shows the income structure of faculty of a particular university in 2000 and 2008. In 2000, incomes from government budget and from funds collected by the university accounted respectively for $32.60 \%$ and $67.40 \%$ of the total income; in 2008 , the respective figures were $21.25 \%$ and $78.75 \%$. The proportion of income from government budget dropped by $11.35 \%$, while funding collected by the university increased by the same percentage. Income also varies significantly among different universities or even among different schools and departments within the same university, which is indicative of how greater independence in decision making influences the faculty management reform.

\section{Conclusion}

Previous research has been done on the academic profession, covering faculty recruitment and employment, remuneration, performance assessment and turnover, but this research is intended to address specific problems rather than the academic profession as a whole. In recent years, some Chinese scholars have been able systematically to compare the academic profession in China with the global situation because they have been involved in an international survey on the academic profession. The most recent publications include the papers by Chen and Shen. ${ }^{26,27}$ Chen analyses the status quo of the academic profession in China and the challenges it faces on the basis of a number of case studies; Shen gives a comprehensive introduction to titles, degrees, age and gender of university faculty based on nationwide statistics.

In my view, it is meaningless to analyse the academic profession in China from the perspective of the international context without paying proper attention 
to the institutions that employ the academic staff. Unlike the above-mentioned papers, this paper puts more emphasis on the analysis of how government and organization influence the academic profession. The major conclusions to be drawn in this respect are the following:

(1) When the new supply-and-demand based market system replaced the planned system, an important guideline for the higher education reform in China was to increase efficiency with (and despite of) limited resources. Following this guideline, greater autonomy has been bestowed on universities in recent years. The Government stopped micro-managing all activities and loosened its control over university and faculty.

(2) Due to the impact of the governmental call for egalitarianism on all levels, personnel management at universities used to be fairly uniform. With the advent of greater autonomy, universities are encouraged to compete and to look for different approaches to faculty management, which results in a range of different personnel management patterns across institutions.

(3) In the context of economic transition, universities (which used to be units largely under government control) are gradually becoming organizations with educational independence, and academic staff are also shifting from danwei men to 'social' men. Comparing the academic profession in two different systems, two typical scenarios can be seen: in a planned system, the academic profession features a unified identity, a similar and average income and a limited scope of activities, while in a market-based system, the profession features a more independent identity, a diversified income structure (with funding originating from government, university and personal channels), more varied income levels, a broader scope of activities and the coming into existence of an academic labour market.

(4) Government has played an important role in pushing forward the changes in the academic profession, in some cases even a more active role than universities themselves. According to a series of government documents that have been issued, since the reform the government's focus has always been on avoiding egalitarianism in income distribution and linking remuneration to individual performance.

(5) Although this paper considers the changes in Chinese society and in the academic profession to be positive, it is undeniable that the academic profession in China in its new form is facing new challenges. For example, China's public units are undergoing further reforms, yet without a definite direction; faculty in public 
universities and those in private institutions are not equal before the law; the ever larger income gap among faculty has yet to be bridged. In addition, how good reform measures such as a unified crediting system for faculty titles and performance-based payment can be implemented in practice is still unclear, and whether a market-based mechanism will be detrimental to Chinese scholars' academic mission remains to be seen.

\section{Acknowledgements}

The author wishes express sincere thanks to Professor Futao Huang at Hiroshima University for the many ways in which he supported this study.

\section{Notes and References}

1. Academic profession in this paper refers specifically to the faculty in higher education institutions in mainland China, excluding research fellows in independent research institutions.

2. G. Rhoades (2007) The study of the academic profession. In: Sociology of Higher Education: Contributions and Their Contexts, edited by P. Gumport (Baltimore: The Johns Hopkins University Press), pp. 113-146.

3. J. Meyer, F. Ramirez, D. Frank and E. Schofer (2007) Higher education as an institution. In: Sociology of Higher Education: Contributions and Their Contexts, edited by P. Gumport (Baltimore: The Johns Hopkins University Press), pp. 187-221.

4. R. Crowson, W. Boyd and H. Mawhinney (1996) Introduction and overview: the new institutionalism and the politics of reinvesting the American School. In: The Politics of Education and the New Institutionalism: Reinvesting the American School, edited by R. Crowson, W. Boyd and H. Mawhinney (Washington, DC: Falmer Press), pp. 1-7.

5. http://www.huaxia.com/zt/tbgz/08-032/1264410.html. Accessed 11 March 2009.

6. http://www.edu.cn/jiao_yu_fa_zhan_498/20080901/ t20080901_321919.shtml. Accessed 11 March 2009.

7. http://www.edu.cn/HomePage/Zhong_guo_jiao_yu/jiao_yu_zi_xun/shu_zi/ jiao_yu_fa_zhan/index.shtml. Accessed 11 March 2009.

8. P. Altbach (2002) How are faculty faring in other countries? In: The Questions of Tenure, edited by R. Chait (Cambridge: Harvard University Press), pp. 160-181.

9. P. Altbach (2007) Transition and Transition: The International Imperative in Higher Education (Rotterdam, The Netherlands: Sense Publishers).

10. F. Yan and Y. Chen (2008) Analyses of educational backgrounds and career paths of faculty in higher education institutions in Beijing municipality, China. In: The Changing Academic Profession in International Comparative and Quantitative Perspectives: Report of the International Conference on the Changing Academic Profession Project, 2008 
(Japan: Research Institute for Higher Education, Hiroshima University), pp. 265-292.

11. A. Walder (1996) Communist Neo-traditionalism: Work and Authority in Chinese Industry (Oxford: Oxford University Press).

12. J. Enders (2006) The academic profession. In: International Handbook of Higher Education, edited by J. Forest and P. Altbach (Dordrecht, The Netherlands: Springer), pp. 5-22.

13. T. Zhou (2008) 30-Years Reform of China's Administrative System (Shanghai: Shanghai People's Press House).

14. The description in Table 2 does not deny that remuneration in some local universities (usually those located in developed areas with higher fiscal revenue) is better than in central universities.

15. F. Yan (2004) The empirical analysis of personnel contract and its incentive in China's private colleges. CHER 17th Annual Conference: Public-Private Dynamics in Higher Education (Enschede: University of Twente) 17-19 September 2004.

16. C. Liu (2008) Study on the Compensation Motivation of Private University Teachers in China. Doctoral Dissertation Proposal (Peking University: The Graduate School of Education).

17. R. Hayhoe and Q. Zha (2006) China. In: International Handbook of Higher Education, edited by J. Forest and P. Altbach (Dordrecht, The Netherlands: Springer), pp. 667-691.

18. 211 refers to a programme aiming at the prioritized building of 100 universities in the 21 st century; 985 is a plan announced by the Chinese government on the occasion of the 100 years anniversary of Peking University in May 1998, in a bid to build several world-class universities.

19. B. Zou (2006) An Analysis of the Income Changes of Faculties in a Chinese University. Doctoral Dissertation Proposal (Peking University: The Graduate School of Education).

20. Data from the Finance Office of PK University in March, 2009.

21. J. Qiao (2008) Academic Ecology Management: Probe into Incentive System for Researching University Teachers (Beijing: Education Science Publishing House), pp. 106-115.

22. Y. Qi and X. Wang (2008) Reform of the internal management system of higher education institutions. In: Review on the Development and Reform of Higher Education in China for Last Thirty Years, China Higher Education Academy (Beijing: Education Science Publishing House), pp. 304-385.

23. The author went on a field study trip to Gansu, Hunan and Jiangsu provinces in September 2008 and found remarkable budget allocations discrepancies among the three provinces.

24. H. Guo (2007) The Financial Differentiation Among Departments in the Research University (Beijing: Peking University Press).

25. The Temporary Measures on Management Responsibilities in Higher Education Institutions (1986) identified eight domains in which higher education institutions have the right to make decisions, some of which are the freedom to hire and discharge faculty, the permission for some designated universities to approve associate professors in accordance 
with relevant regulations, the permission for a few eligible universities to approve professors, the independence in disciplinary setup at the level of graduate studies, and the independence in appointing doctorate supervisors. Article 18 in the Outline for Educational Development and Reform in China (1993) made it clear that it is necessary to expand independence for higher education institutions in budget allocation, titles assessment and approval, income distribution and faculty management. Article 37 in the Higher Education Law (1998) stipulated that higher education institutions were allowed to hire faculty and other staff with a specialty and adjust arrangements for allowance and salary distribution in accordance with state regulations. Article 19 in the Decisions on Deepening Comprehensive Education Reform to Implement Education for All-round Development (1999) repeated that higher education institutions are allowed to recruit and hire faculties independently. Article 5 of The Teachers' Law (1993) stipulated that teachers in higher education institutions shall be at least above bachelor degree and that schools and other educational institutions shall gradually carry out a teacher employment system.

26. X. Chen (2005) Academic profession in China. In: The Decline of the Guru: The Academic Profession in Developing and Middle-Income Countries, edited by P. G. Altbach (Qingdao: China Ocean University Press), pp. 92-113.

27. H. Shen (2006) Academic profession in China: with a focus on the higher education system. In: Reports of Changing Academic Profession Project Workshop on Quality, Relevance, and Governance in the Changing Academia: International Perspective (Japan: Research Institute for Higher Education, Hiroshima University), pp. 79-96.

\begin{abstract}
About the Author
Fengqiao Yan is Professor of higher education research at the Graduate School of Education of Peking University. He specializes in sociological and organizational analyses of higher education phenomena and has participated in a number of research projects on the development of private higher education in China (supported by World Bank and the Ford Foundation) and on academic professions in China (supported by the Chinese research council).
\end{abstract}

